\title{
Mangfoldighed længe leve!
}

Dansk Universitetspædagogisk Tidsskrift har nu eksisteret $i$ to år, dvs. fire numre. Det har været to spændende år med mange - forskellige - artikler dels inden for de fire temaer: bedømmelse og feedback, udvikling af underviserkompetencer, vejledning og de senmoderne studerende og dels artikler om andre universitetspædagogiske emner. Tidsskriftet har altså i opstartsfasen været relativt stramt struktureret omkring nogle temaer for at give anledning, inspiration og mulighed til universitetspædagogiske skribenter 'derude'. I redaktionen føler vi imidlertid, at tiden nu er moden til at slippe tøjlerne lidt mere, og har stor tiltro til, at der findes et hav af universitetspædagogiske artikler derude, som bare venter på at blive skrevet og ikke kan vente til det rette temanummer dukker op. Derfor har vi fra dette nummer forsøgt os med et tidsskrift, som har et bredt udvalg af universitetspædagogiske artikler suppleret med et par artikler om et på forhånd fastlagt tema. På denne måde håber vi at have styrket tidsskriftets aktualitet og alsidighed. Temaerne opstår muligvis med tiden igen af sig selv - fx på baggrund af aktuelle uddannelsespolitiske tiltag.

Artiklerne i dette nummer kommer således vidt omkring: fra artikler, som inspirerer i kraft af deres videregivelse af praktiske erfaringer med undervisningsog uddannelsesforløb, til artikler, som inspirerer i kraft af deres teoretiske overvejelser om undervisnings- og uddannelsesforløb. Artiklernes emner spænder ligeledes vidt: fra portfolioevaluering over virtuelle læringsmiljøer til projektpædagogik. Dog er variansen i forfatternes (og dermed i de fleste tilfælde også artikelindholdets) fagområder ikke så stort, selvom vi i dette nummer både hører fra historie, spansk, pædagogiske og samfundsvidenskabelige uddannelser samt generelle overvejelser om projektarbejde, fjernundervisning og vejledning, som i princippet kan gælde for alle fagområder. Ikke desto mindre vil vi fra redaktionen gerne se flere artikler om og fra de naturvidenskabelige, tekniske og sundhedsvidenskabelige miljøer. Ikke kun fordi vi ved, at der også her foregår spændende og relevante universitetspædagogiske tiltag, men også for at sikre tidsskriftets mangfoldighed og inspirationskraft fremover.Vi glæder os til at modtage jeres artikelforslag!

Dette nummer indledes med Gerd Christensens artikel, 'Vejledning mellem magt og afmagt', som er en diskussion af vejlederens rolle og funktion i projektarbejdet. Magt/afmagt temaet i overskriften hentyder til vejlederens formelle magt som endelig bedømmer af projektet, samtidig med at vejlederen oplever en vis afmagt i forhold til de studerendes bedømmelse og karakterisering af den gode og den dårlige vejleder ud fra kriterier, som ikke altid er entydige. Dette stiller store krav til vejlederen - ikke alene skal han/hun have et stort fagligt overblik (større end som underviser, fordi de studerende i projektet som regel sætter pensum), men også en veludviklet social kompetence for at kunne aflæse, hvilken slags vejlederrolle de studerende/ projektet har brug for (eller efterspørger, hvilket ikke altid er det samme).

Maria Hvid Stenalt og Tine Wirenfeldt Jensen giver sig i artiklen 'Hvad er et godt virtuelt læringsmiljø? Betydningen af klimaet i det medierede læringsrum' i kast med projektet at aptere dette nye læringsrum med de bedste af dyderne fra sociale face-to-face rum, som vi kender dem fra kollokvier, seminar- og gruppeundervisning. Disse dyder udfolder sig bedst, når undervisningsindhold og -form medfører, at medlæringen understøtter læringen, og når de studerende har tillid til det, der foregår, fordi rummet inviterer til, at man har ret til at komme ind i det, som 'god nok som man er i udgangspunktet' for med dette udgangspunkt at påbegynde det mere møjsommelige arbejde med at erhverve de nye kvalifikationer. Man kunne også sige, som forfatterne gør, at klimaet skal være inviterende for at skabe mulighed for 'constructive alignment' eller dybdegående læring med en reference til Biggs. I artiklen undersøges og sammenlignes det virtuelle rum med face-to-face undervisning, og forfatterne ender med at 
konstatere, at de virtuelle systemer skal åbnes (udvikles interaktivt), så de faciliterer læringen på samme måde, som realundervisningen gør, når den er bedst.

I artiklen 'Fra mundtlig gruppeeksamen til løbende evaluering med portfolio' undersøger Lone Ambjørn på en måde de samme aspekter som Stenalt og Wirenfeldt gør i deres artikel. Det gør hun ved at reflektere over den praksis, hun har indført som erstatning for gruppeeksamen i 'Spansk kommunikation' på BA-studiet. Gennemgående og erstattende elementer er portfolio og etablering af en e-læringsplatform. Spansk kommunikation må i sagens natur være mere end noget, man kan gøre alene. Det kommunikativt trænende lægger Lone Ambjørn derfor i en face-to-face undervisning, mens en række reflektoriske arbejdsgange lægges $i$ arbejdet med portfolioen og i e-læringsrummet. Lone Ambjørn får demonstreret en kreativ vej ud af opgaven med at erstatte den positive washback fra en gruppeeksamenssituation med en løbende evaluerende og metakognitiv praksis hen over undervisningsforløbet. I artiklen får vi også overvejelser over, hvordan man kan gribe det læringssocialiserende an i forhold til det at lave spilleregler for, hvordan man arbejder i e-læringsrum.

Overvejelser om og bevidstgørelse af spillereglerne i en undervisningssituation finder vi også i Tina Bering Keidings artikel,'Projektmetoden - en systemteoretisk genbeskrivelse'. Med det erklærede mål at bidrage til en fornyelse af projektarbejdets teoretiske didaktik bliver vi i artiklen, med afsæt $\mathrm{i}$ et historisk rids af projektarbejdets fødsel og ungdom, ledt gennem systemteoriens begreber og hen til en genbeskrivelse af centrale elementer i projektarbejdet. Tina Bering Keiding foreslår $\mathrm{fx}$, at vi begynder at tale om et projekts hensigt i stedet for dets problemformulering, da hensigtsformuleringen i højere grad understreger, at et projekt, med Luhmannske termer, lader sig påvirke af deltagerne, men i princippet styrer sig selv og dermed umuliggør den fastlåsning af orientering, som en problemformulering leder tankerne hen mod. Spillereglerne for projektarbejde ændres således på tilsvarende manér til at fokusere bevidst på at opøve de studerendes evne til at reflektere over deres eget og projektets stadigt forandrede læringspotentiale. Og det kræver både noget (nyt) af de studerende, af underviserne og af det institutionelle undervisningssystem som helhed.

At sætte andre rammer for undervisningen optager også Monika Janfelt. I artiklen 'Lærende relationer - coaching og undervisning' videregiver hun sine erfaringer med at implementere coachingredskaberne, Appreciative Inquiry og Ability Spotting, i et undervisningsforløb for 1. års historiestuderende. I en fremlæggelsesseance, hvor de studerende har fået til opgave at give en mundtlig fremstilling af en historisk problemstilling, beskriver Monika Janfelt, hvordan hun bevidst søger at kommentere udelukkende på gode præstationer og ikke at fokusere på faglige mangler i oplægget. Ud fra et coachingmæssigt synspunkt er det nemlig vigtigt at have et konstruktivt fokus på personens evner, potentialer og de læringspotentialer, der ligger i personens egne erfaringer. Denne tilgang til de studerendes læringsproces kan, efter Monika Janfelts mening, også med fordel applikeres til underviserens opfattelse af sig selv som reflekterende underviser.

Som nævnt ovenfor har redaktionen i forbindelse med dette nummer, temaløsheden til trods, alligevel udsendt en lille invitation til artikler inden for et bestemt tema, nemlig 'Videre- og efteruddannelse på de højere læreanstalter - en ny pædagogik?'. Det er der kommet to artikler ud af, som hver især behandler spørgsmålet om, hvordan den 'anden slags' studerende, som studerende på universiteternes masteruddannelser i generelle vendinger er, kunne tænkes undervist. Udfordringerne ved at inddrage de studerendes praktiske viden $\mathrm{i}$ en teoretisk (efter)uddannelse står centralt i de to artikler.

Vibe Aarkrog behandler i artiklen 'Masterstuderendes kobling af teori og praksis. Inspiration til videreudvikling af masterpædagogikken?' problematikken ud fra halvårlige evalueringsundersøgelser blandt masterstuderende på Danmarks Pædagogiske Universitetsskole, Aarhus Universitet om bl.a. deres indtryk af undervisningens evne til at koble teori med praksis. Resultatet fra disse evalueringer sammenholder Vibe Aarkrog med tidligere forskning og kommer frem til fem kategorier som beskrivelser af at koble teori med praksis. I et fremadrettet perspektiv er det naturligvis ikke hensigten at rangordne de fem kategorier, så én teori-praksis kobling er mere værd for studerende eller undervisere end en anden, men blot at synliggøre, at der findes forskellige former for kobling. Denne variation i koblingerne kan med fordel tages op i forskellige situationer - både teoretisk som en bevidstgørelse hos de studerende om deres udbytte af uddannelsen og praktisk som et udgangspunkt for forskellige undervisningsformer på uddannelsen.

Netop denne praktiske tilgang til teori-praksis koblingen kommer J. C. Ry Nielsen ind på i sin artikel 'Deltagerorienteringen i undervisningen af MPA studerende - refleksioner og praksis'. Her trækker han nemlig på sin lange erfaring som udvikler af og underviser på Master of Public Administration og beskriver nogle af de konkrete tiltag, som han som studieleder for programmet $i$ en lang årrække har stået i spidsen for. Artiklen demonstrerer, at undervisning på masteruddannelser $i$ virkeligheden har et meget mere privilegeret udgangspunkt end BA- og kandidatuddannelser, idet man straks kan tage (induktivt) udgangspunkt $i$ praksis. På kandidatstudierne er man ofte nødt til at arbejde med en 'som-om-virkelighed' eller, endnu mere ydmygt, alene at være overladt til at arbejde deduktivt fra et teoriudgangspunkt i lønligt håb om, at dette på et tidspunkt ramler frugtbart ind i praksis. Faktisk kan erfaringerne fra masteruddannelserne føre til et skær- 
pet blik på nødvendigheden af og frugtbarheden af i sekvenser på kandidatuddannelserne at mime praksis for på den måde at skærpe teori/praksis interaktionen og på den måde tilføre disse uddannelser masteruddannelsernes medfødte kvalitet. At masteruddannelser er blevet en fast bestanddel af det universitære arbejde har således bidraget til frugtbare cross-over erfarings- udvekslinger mellem induktive og deduktive udgangspunkter. Dem demonstrerer Ry.

Afslutningsvis bringer vi en boganmeldelse, og sådan kom vi i dette nummer vidt omkring. Tilbage er nu kun at ønske alle god læselyst - vi håber at høre fra jer! 